\title{
Beatrice Saletti
}

University of Ferrara

\section{IMITATION GAMES. SOME NOTES ON THE ENVOYS SENT BY BORSO D'ESTE TO UTHMAN, RULER OF TUNIS}

\begin{abstract}
In April 1464 Borso d'Este, Lord of Ferrara, sent two of his servants to Tunis in order to purchase prized horses, giving precise instructions for offering his regards and presenting his gifts to the ruler of Tunis. The letter that the Marquis entrusts to his two servants is a mine of information, because Borso leaves nothing to chance. His instructions cover every aspect of the ambassadorial visit: when to show the gifts, how and in what order to show them, the speech to be given. Many of the instructions given to ambassadors by their governments are yet to be investigated: how much room for manoeuvre did they leave in achieving the objectives of the mission, for example? In the case of the Marquis of Ferrara, Borso intends to exhibit his kingship through the staging of the presentation of his gifts, and through the posture, the gestures and the words of his representatives. The analysis of his letter can offer an interpretative guide for examining the appearances and public celebrations organized by Borso during his rule, which took place in an age of great experimentation.
\end{abstract}

Keywords: Italian Renaissance diplomacy, Borso d'Este, Caliph Uthman, gift-giving, Abbasid, Tunisia

Inspired by two exchanges of the mid-fifteenth century between Tunis and Ferrara, this study reflects on gifts, diplomacy, politics and social customs. The exchanges in question are the delegations sent respectively by the Lord of Ferrara to Uthman, the ruler of Tunis, ${ }^{1}$ in the spring of

1 Uthman was an independent amìr, but for Europeans he was a 'King'. 
1464 and from Uthman to Borso ${ }^{2}$ during the following winter. Gifts and their symbolism in human societies became a subject of research in the twentieth century: first for anthropologists, then for sociologists and cultural historians. ${ }^{3}$ At a general level, gifts are, to some extent, a representation of the identity of the giver. ${ }^{4}$ Given that diplomacy thrives on symbols and representations, which by their nature are polysemous, the study of diplomatic gifts can be a rich mine of information for historians. For example, in $801 \mathrm{CE}$ the Caliph al-Rashid gave Charlemagne, among other things, a very rare albino elephant, and in 807 he gave him monkeys and a mechanical bronze watch. These gifts exhibited both the technological excellence of the Abbasid culture and the wealth and diversity of the kingdom ruled by the Caliph. ${ }^{5}$ To seal the Treaty of Tilsit, Napoleon gave Tsar Alexander a porcelain dinner service from Sèvres, which represented the pride of French artistic production. ${ }^{6}$

2 The lineage assumed the title of Marquis of Este in the eleventh century, and it ruled Ferrara as holder of a vicariate granted by the pope from the thirteenth century onwards. Borso therefore was the Lord of Ferrara, but not the Marquis of Ferrara, and the title of Duke of Ferrara was not granted to him until April 1471, about four months before his death. For these reasons, to simplify, I will only refer to 'Marquis' Borso in this study.

${ }^{3}$ On the nature, meaning and function of the gift in groups and cultures it is mandatory to cite the fundamental work by Marcel Mauss, 'Essai sur le don. Forme et raison de l'échange dans les sociétés archaïques', L'Année sociologique, 1, second série (1923-24); and subsequent scholars after him, such as David Cheal, The Gift Economy (London: Routledge, 1988); and Maurice Godelier, L'Énigme du don (Paris: Fayard, 1996). Historians have also dealt with the specific characteristics that gift-giving assumed in the contexts they examined: for example Natalie Zemon Davis, The Gift in Sixteenth-Century France (Oxford: Oxford University Press, 2000); Negotiating the Gift: Pre-Modern Figurations of Exchange, ed. by Gadi Algazi, Valentin Groebner, Bernhard Jussen (Göttingen: Vandenhoeck \& Ruprecht, 2003); The Languages of Gift in the Early Middle Ages, ed. by Wendy Davies, Paul Fouracre (Cambridge: Cambridge University Press, 2010).

${ }^{4}$ For a clear example of an analysis of diplomatic gifts as tools of self-representation and political legitimation, see: Valentin Groebner, Liquid Assets, Dangerous Gifts: Presents and Politics at the End of the Middle Ages (Philadelphia: University of Pennsylvania Press, 2002), p. 44.

5 Francis W. Buckler, Harunu'l-Rashid and Charles the Great (Cambridge: Mediaeval Academy of America, 1931), p. 42.

${ }^{6}$ Bernard Chevallier, 'Sévres et l'Egypte', in Napoleone Bonaparte in Egitto: una spedizione tra conquista e conoscenza 1798-1801, ed. by Cristina Cannelli, Giulia Gorgone, Luigi Mascilli Migliorini (Roma: Gangemi, 2000), p. 67. 


\section{TUNISIA AND ITALY}

Before going into the details of the delegation sent to the Maghreb by Borso d'Este, it might be useful to examine the historical context concerning Tunisia and its primary Italian partners. Tunisia was at the heart of the caravan traffic between sub-Saharan and north-west African countries on the one hand and Egypt and its neighbours on the other hand. From 1229 until the Ottoman conquest (1573), Tunisia was ruled by the Hafsid dynasty. The first Hafsid ruler of Tunisia, Abu Zakariyya, is famous for his construction of markets in Tunis and his support for commercial institutions. During his reign, several communities of European merchants were allotted warehouses in Tunis harbour so that they could trade. Pisa was the first Italian state whose merchants established residence in Tunis: a warehouse for Pisan merchants and their families was mentioned in a treaty as early as $1157 .{ }^{7}$ In the following centuries, the Hafsids continued to renew the treaty with Pisa until 1421, when Florence conquered the city and its harbour. Then Florence started to rival Genoa in the Western Mediterranean, especially along the shores of Tunisia and aspired to compete with Venice in the trade of spices from the Near East. ${ }^{8}$ In 1231, Venice and Abu Zakariyya signed a forty-year treaty, and Genoa obtained its first commercial treaty with Abu Zakariyya in $1236 .{ }^{9}$ The kingdom of Tunis controlled the maritime access route which connected the Aragonese territories and the Levant. The Hafsids were so closely related to the kingdom of Sicily that, when the Angevin dynasty supplanted the Swabian dynasty, Tunis refused to recognize its sovereignty. ${ }^{10}$ From the end of the fourteenth century, due

7 Olivia Remie Constable, Housing the Stranger in the Mediterranean World: Lodging, Trade, and Travel in Late Antiquity and the Middle Ages (Cambridge: Cambridge University Press, 2003), pp. 128-33.

8 Raúl González Arévalo, 'Italian Renaissance Diplomacy and Commerce with Western Mediterranean Islam: Venice, Florence, and the Nasrid Kingdom of Granada in the Fifteenth Century', I Tatti Studies in the Italian Renaissance, 18 (2015), pp. 215-32.

9 Dominique Valérian, 'Gênes, l'Afrique et l'Orient: le Maghreb almohade dans la politique génoise en Méditerranée', in Chemins d'outre-mer: Études d'histoire sur la Méditerranée médiévale offertes à Michel Balard, ed. by Damien Coulon, Catherine Otten-Froux, Paule Pagès et al. (Paris: Publications de la Sorbonne, 2004), pp. 827-37.

10 Francesco Cerone, 'La politica orientale di Alfonso di Aragona', Archivio Storico per le Province Napoletane, 27 (1902), 380-456 (p. 385). 
to a drastic decline in agricultural and manufacturing production in the Mamluk empire, European merchants importing oriental products such as spices and corals to the West, began selling fabrics (cotton and wool), wheat and oil to Egypt, both from Italy and from the Maghreb. The majority of the shipping trade of Maghreb merchandise was in European hands, but the Hafsid rulers made a considerable amount of money through taxes and duties on European exports. ${ }^{11}$

In the case of the Marquis Borso d'Este, his relationship with Tunis did not depend on foreign affairs. The Este possessed valleys, salt pans and mines, and resold raw materials both to their own subjects and outside their domain. They also owned numerous commercial enterprises: ovens, mills, inns, taverns and so on. ${ }^{12}$ Furthermore, passing through Ferrara was unavoidable for anyone travelling to Venice either from the north or the centre of Italy, and the Este exploited this position by charging travellers high prices for goods ${ }^{13}$ Nevertheless, the Este state had no direct maritime interests. From 1325, Comacchio, a town near the Adriatic Sea, was acquired by the Este family. Still, the power of Venice to the north, and of the Pontiff to the south, prevented the Este family from exploiting the potential of its port. It was probably with the aim of protecting Ravenna and its harbour from future aggression that Sigismondo Malatesta, in 1461, sent a diplomatic mission to Constantinople, and to the Ottoman sultan. ${ }^{14}$ The commercial strength of the Este did not reside in maritime trade but rather in the vastness of

11 Dominique Valérian, 'L'essor de l'activité commerciale de la façade maritime du Maghreb aux XIII ${ }^{e}$ et XIV siècles', in Les ports et la navigation en Méditerranée au moyen âge, ed. by Ghislaine Fabre, Daniel Leblévec, Denis Menjot (Paris: Editions du Manuscrit, 2009), pp. 229-30.

12 Guido Guerzoni, La colonia sotto casa (Torino-London: Umberto Allemandi \& C., 2008), pp. 19-26.

13 Beatrice Saletti, 'Assente ingiustificata. Per la storia economica di Ferrara nel Tre e Quattrocento', in Centri di produzione, scambio e distribuzione nell'Italia centro-settentrionale. Secoli XIII-XIV, ed. by Bruno Figliuolo (Udine: Forum, 2018), 177-201 (pp. 178-79).

14 Some gifts destined for the sultan were the reason (or the excuse) for the Venetian authorities in Crete incarcerating the envoy Matteo de' Pasti. Therefore, the mission never took place; see: Sean Roberts, 'The Lost Map of Matteo de' Pasti: Cartography, Diplomacy, and Espionage in the Renaissance Adriatic', Journal of Early Modern History, 20 (2016), 19-38. 
their agricultural and forest lands. This being the case, the connection between Borso and Abu Oman Uthman is to be found elsewhere. Like so many nobles of that period, Borso was passionate about horses and sent his employees to procure them from England, Ireland, Sicily, and even Africa. The Marquis paid so much attention to his animals (and horses in particular) that he went on to write to one of his referendari that he would prefer to go with no food himself than let his horses starve. ${ }^{15}$ In 1463, Borso sent an envoy to Tunis to buy exotic animals, and the mission yielded ten horses, two lions, two ostriches and several dogs, to which Uthman added a personal gift to Borso: no need to say that it was a horse. ${ }^{16}$ Unfortunately, this first mission did not leave behind many documents. In April 1464, Borso sent two squires to Tunis, to again buy horses and reciprocate Uthman's gift. The long letter in which the Marquis explains to his squires every aspect of their mission has been preserved. ${ }^{17}$

\section{BORSO'S RULE IN THE CONTEXT OF ITALY}

Ruling from 1450 to 1471, Borso d'Este was the most popular lord of Ferrara of that century. Rival to Milan and Florence, an ally to Venice and supporter of the Anjou dynasty, Borso managed to obtain two ducal investitures: the imperial duchy of Modena (1452) and the pontifical duchy of Ferrara (1471). ${ }^{18}$ Having secured these credentials, Borso placed himself on the same level as the Dukes of Milan, and a higher level than the Marquis of Mantua and Urbino. The investitures were

15 Archivio di Stato di Modena (hereafter cited as ASMo), Camera Ducale, Carteggio di referendari, consiglieri, cancellieri e segretari, Letter from Marquis Borso d'Este to his referendario, 5 August 1454, b. 2 b.

16 Relazioni dei Duchi di Ferrara e di Modena coi Re di Tunisi, ed. by Cesare Foucard (Modena: Litografia Pizzolotti, 1881), p. 8.

17 ASMo, Carteggio principi esteri, Ambasciatori dal Levante, b. 1, published in Relazioni dei Duchi, pp. 9-18, translated into English in Italian Renaissance Diplomacy: A Sourcebook, ed. by Monica Azzolini and Isabella Lazzarini (Durham-Toronto: Institute of Medieval and Early Modern Studies, Durham University-Pontifical Institute of Medieval Studies, 2017), pp. 195-202.

${ }^{18}$ Luciano Chiappini, 'Borso d'Este', Dizionario Biografico degli Italiani (Roma, Istituto dell'Enciclopedia Italiana, 1960-), XIII (1971), pp. 134-43. 
part of his plan to expand his state, but his countless attempts to do so, although extremely skilled, proved ineffective. The paradigms of Borso's intense diplomatic activity are yet to be studied; therefore it will not be possible here to set the Tunisian episode within the broader framework of his government and in the even more expansive context of contemporary Italian diplomacy. ${ }^{19}$

The evolution of modern European diplomacy has been strongly influenced by medieval Italian diplomacy. Within that field, the small but cosmopolitan Italian states of the period were at the forefront. To quote Isabella Lazzarini, 'Renaissance Italy proved to be a landscape in which diplomatic languages, practices and tools grew and became pivotal not only for Italy itself but also for the European continent as a whole'. ${ }^{20}$ During the fourteenth century, the most potent Italian governments exercised a recognizable diplomatic agency. The fact that the most powerful states had developed their own ceremonials was evident also to the subjects of the minor states: two ambassadors from Siena, sent to Naples to attend the marriage of Ferrante of Aragon, wrote to their government on 19 May 1445: 'We will try to make the best of it: the other ambassadors were instructed by their lordship on the way to behave, only we are without manners' ${ }^{21}$ The ambassadors, therefore, informed the Siena authorities that, in order not to appear clumsy or provincial in delivering diplomatic gifts, they would imitate the behaviour of their Venetian and Milanese colleagues. In 1438, Alfonso of Aragon had chosen the Benedictine monk Giuliano Maiali as the ambassador to be sent to Tunis for his intellectual and moral skills: Maiali was the founder of the largest hospital in Palermo and was known for his fervent faith. ${ }^{22}$ During the brief period when Genoa was

19 An overview of the most recent studies of late medieval and early modern diplomatic history in Tracey A. Sowerby, 'Early Modern Diplomatic History', History Compass, 14, no. 9 (2016), 441-56.

${ }^{20}$ Isabella Lazzarini, Communication and Conflict: Italian Diplomacy in the Early Renaissance, 1350-1520 (Oxford: Oxford University Press, 2015), p. 7.

${ }^{21}$ Angelo Morosini and Pietro Micheli to the Concistoro di Siena, Naples, 19 May 1445, in Dispacci sforzeschi da Napoli: 4 luglio 1454 - 30 dicembre 1459, ed. by Francesco Senatore (Salerno: Carlone, 1997), p. 28.

22 Bruno Figliuolo, 'La Terrasanta nel quadro della politica orientale di Alfonso V d'Aragona', Nuova Rivista Storica, 100, no. 2 (2016), 483-515 (p. 493). 
a protectorate of Milan, the Duke of Milan chose to send the Bolognese Cambio Zambeccari to Tunis. Doctor of law, Zambeccari had reached a prominent position in the Visconti court, assuming important official roles such as the commissioner of Milan and captain of the guards. ${ }^{23}$ Apart from the short Milanese parenthesis, Genoa used to entrust diplomatic missions to members of its aristocracy and economic elite, such as Andrea de Mari and Ambrogio Spinola, before or after naming them consuls in Tunis. ${ }^{24}$ The choices of the Republic of Venice were similar to that of Genoa: diplomatic messages or specific missions were usually entrusted not to ambassadors, but to Venetian consuls in Tunis. ${ }^{25}$

Borso's choice was, instead, to send two squires to Tunis: Francesco Gattamelata and Giovanni Giacomo della Torre. He never referred to them as 'ambassadors', and they were neither noble nor cultured. They were experts in evaluating horses: in his instructions, the marquis asked for sturdy beasts, two horses and two mares - either draught horses or trotters - and, to find them, the squires were allowed to travel up to 100 miles from Tunis. Since Gattalemata knew Borso's taste, after the trip to Tunis, he would have to go to Sicily to buy some more horses. That was the primary mission.

In his detailed letter, Borso commanded his squires to maintain irreproachable behaviour. He clearly explained that as the representatives of one of the most powerful lords in Italy, any misconduct on their part would bring dishonour on their sovereign:

Remember to behave on this ship in such a manner and in such a way with words, gestures, and your dealings with others that you demonstrate to be servants worthy of any great lord. Behave in such a way that others understand that you have done your job honourably, and the captain of the ship can praise you as courteous and well-mannered people [...]. [In Tunis] you [...] will behave so pleasingly, behaving

${ }^{23}$ Lodovico Frati, 'Due umanisti bolognesi alla Corte ducale di Milano', Archivio Storico Italiano, 5th ser., 43 (1909), 359-73 (pp. 367-68).

24 Giovanna Petti Balbi, 'L'emirato hafside di Tunisi: contatti e scambi con il mondo cristiano (secc. XIII-XVI)', in Africa / Ifrìqiya. Il Maghreb nella storia religiosa di Cristianesimo e Islam, ed. by Luciano Vaccaro (Città del Vaticano-Gazzada: Libreria editrice vaticana-Fondazione ambrosiana Paolo VI), 329-43 (p. 334).

25 Alberto Sacerdoti, 'Venezia e il regno Hafsida di Tunisi. Trattati e relazioni diplomatiche (1231-1534)', Studi Veneziani, 8 (1966), pp. 318-44. 
discreetly with habits and manners such that everyone knows that you are the servants of an honourable lord. You should avoid women and all lascivious things, by which others could get a bad impression of you or you could create a scandal, remembering that you are not in Francolino but far away. ${ }^{26}$ Behave honourably and politely with everyone, so that your behaviour reflects the courteous court from which you come. ${ }^{27}$

While the Genoese and Venetian governments explained in their instructions to ambassadors how to carry out the mission, they also ordered them to request updated information from the community of their fellow merchants residing in Tunis, to adapt the information in their possession to the latest events. This was the case, for example, for Andrea de Mari, who in 1432 was entrusted with a mission whose goal was to free Genoese ships and citizens captured by Uthman. ${ }^{28}$ Although Borso had no international economic interests which would require a diplomatic apparatus comparable to those of Genoa or Venice, he was aware of the usefulness of this process, and, in one of his letters, he invites the squires to be instructed and advised by the Genoese consul of Tunis, Clemente Ciceri:

When you arrive in Tunis, your first shelter and resting place will be with sir Clemente Ciceri, our most cordial and special friend, from whom you will get information, introductions, and advice, and will know if His Majesty the king is there or elsewhere. According to what he thinks, he will advise you. ${ }^{29}$

Seeking advice from the consul may seem obvious, but, for example, the Florentine government, after the conquest of Porto Pisano, did not adopt this practice: the report by the diplomat Felice Brancacci, sent to Cairo in 1421 to obtain valuable commercial agreements, describes

${ }^{26}$ Francolino is a small village in the countryside of Ferrara, which today has fewer than 2,000 inhabitants.

27 Letter from Marquis Borso of Este to his squires Francesco Gattamellata and Giovanni Giacomo dalla Torre, April 1464, in Italian Renaissance Diplomacy, pp. 213-15.

${ }^{28}$ Emilio Marengo, 'Genova e Tunisi (1388-1515)', Atti della Società Ligure di Storia Patria, 5th ser., 32 (1902), p. 146.

29 Letter from Marquis Borso of Este to his squires Francesco Gattamellata and Giovanni Giacomo dalla Torre, April 1464, in Italian Renaissance Diplomacy, p. 196. 
several times his innumerable difficulties resulting from ignoring the practices of the Mamluk administration. ${ }^{30}$

\section{DIPLOMATIC GIFTS TO THE HAFSID}

The Mamluk kingdom of Egypt and Syria imported commodities from the Maghreb, including slaves, leather and, in particular, horses. Horses were the usual diplomatic gifts from the Hafsid to Mamluk rulers (and, as we shall see, to anyone else). During 1397 and 1398, the master of the stables of the Sultan Barquq was sent to Tunis to buy horses for his master and came back to Cairo with gifts from the Amir Abū Fāris 'Abd al-'Aziz II: horses and mules with luxurious trappings, swords made from gold and silver, and precious textiles. ${ }^{31}$ Not much is known about the diplomatic gifts that Italian rulers gave to the 'Kings' of Tunis. At every dynastic succession, Genoa and Venice had to obtain the renewal of commercial treaties from the new ruler, and administrative records describe these procedures as routine assignments. As regards Venice, I have identified only four notes on the extent of the gifts sent to Tunis, which are almost all for the same value:

21 April 1399 - 100 ducats;

9 June 1401 - 100 ducats;

7 April 1427 - 12 liras;

29 December $1489-100$ ducats. $^{32}$

30 Dante Catellacci, 'Diario di Felice Brancacci ambasciatore con Carlo Federighi al Cairo per il comune di Firenze', Archivio Storico Italiano, 8th ser., 8 (1881), 157-88 (pp. 165-85).

31 Doris Behrens-Abouseif, Practising Diplomacy in the Mamluk Sultanate (London: Tauris, 2014), p. 53.

32 The dates in the list refer to the days on which the Senate of the Venetian Republic approved the delegations (and the nature of the gifts). As for the March 1489 delegation, Venice already knew that the new ruler, Abd al-Mu'min, had taken office in Tunis. The Venetian Senate therefore contacted the captain of the Trafego galley, who had already reached Istria, and ordered him to go to Tunis to pay homage to Abd al-Mu'min. The gift had not been planned by Venice, and can be seen as a selection of goods already on the galley. It consisted of six forms of precious Piacenza cheese and some prized fish: Marino Sanudo il Giovane, Le vite dei dogi (1474-1494), ed. by Angela Caracciolo Aricò, 2 vols (Roma-Padova: Antenore, 1989-2001), I (1989), p. 614. It was too humble a gift and was improved upon the following winter. 
In 1425, the Duke of Milan, while sending an ambassador to Tunis as the ruler of Genoa, wrote to tell his secretary to buy two sets of armour: one for King Abū Fāris mentioned above, and one for his son. Metal processing, the armoury in particular, was the pride of Milanese craftsmanship; the value of the King's armour was 170 liras. ${ }^{33}$ Marengo's work on Genoa remains fundamental to a study of this topic and contains transcripts of numerous diplomatic documents, but among the variety of information it provides, there is nothing relating to gifts offered, nor to those received. ${ }^{34}$

As for the crowns of Sicily and Naples, a recent work by Figliuolo appeared, based on the now outdated study by Cerone. Yet both of them focus only on the rule of King Alfonso V of Aragon (King of Naples from 1442 to 1458). Alfonso had become king of Aragon in 1416, and for over thirty years had chased the goal of becoming King of Naples, before finally succeeding. His political project aimed at expanding the Catalan area of influence in the central Mediterranean, encouraging local production and trading with Cyprus, the Balkan Peninsula, and North Africa. ${ }^{35}$ Figliuolo reports some gift exchanges between Sicily and Tunis between 1438 and 1454, also identified thanks to accurate archival research. Still, he does not detail them all, because he is instead interested in the sovereign's very complex Eastern policy. Uthman sent the King several horses, lions and a leopard; in return, Alfonso sent precious Western textiles. ${ }^{36}$

${ }^{33}$ Letter from Duke Filippo Maria Visconti to his secretary Zannini Ricio, 28 November 1425, in Luigi Osio, Documenti diplomatici tratti dagli archivi milanesi (Milan: Tipografia di Giuseppe Bernardoni di Giovanni, 1869), pp. 163-64.

${ }^{34}$ Marengo, 'Genova e Tunisi'. The more recent works by Petti Balbi very effectively investigate other aspects of diplomacy, such as the structure of consulates and the careers of ambassadors and consuls: Giovanna Petti Balbi, 'Il consolato genovese di Tunisi nel Quattrocento', Archivio Storico Italiano, 156 (1998), pp. 227-56; ead., 'Gli insediamenti genovesi nel Nord-Africa durante il '400', in Medioevo, Mezzogiorno, Mediterraneo. Studi in onore di Mario del Treppo, ed. by Giovanni Vitolo and Gabriella Rossetti (Pisa-Naples: GISEM-Liguori, 2000), pp. 121-37; ead., Negoziare fuori patria: nazioni e genovesi in età medievale (Bologna: Clueb, 2005).

35 Alan Ryder, Alfonso the Magnanimous: King of Aragon, Naples, and Sicily, 1396-1458 (Oxford: Clarendon Press, 1990).

36 Figliuolo, 'La Terrasanta nel quadro', pp. 493-96. 
If we compare these items with Borso's list, the variety of gifts alone denotes the careful planning and originality with which Borso wanted to distinguish himself. He offered to Uthman:

Eight mules, with brocaded silk mantles; a saddlebag and a hunting bag made with woven gold and silk textiles, as for a king; a Murano glass table service for the king; twelve knives, those from Master Luca; two chairs of gold brocade; the ivory box; two straw hats; twenty-five big and fine rounds of cheese; a dozen flasks, covered with gilded leather; a kings' sword, with a sheath of gold and silk in the shape of a bag; a dozen dog chains with collars. ${ }^{37}$

For Uthman's son, the gifts were:

A breastplate; two beautiful and well-furnished crossbows, with boxes for holding the arrows, arrows, and firing levers; two small guitars, with many strings, and their cases; two pairs of nice hunting dogs, counting the one taken by Bolze; a dozen gloves for goshawks and sparrowhawks keeping the birds on the arm (six pairs for the goshawks. And six for the sparrowhawks); one hundred pairs of bells, of two types, that are in total two hundred; two of the most beautiful and finest straw hats, made in our tradition; four beautiful knives, those of Master Luca; four beautiful dog collars and two leashes of silk and gold; a rod for the sparrowhawk, with cloth made in our custom; twelve beautiful boar spits from Modena; two mules covered in silk; three pairs of falcon gloves. ${ }^{38}$

Borso had a very acute sensitivity about his image, which has been emphasised more by art historians than by historians in general. Borso almost always dressed in gold and wore gaudy jewels. His ostentatious luxury earned him reproaches from Pope Paul II, to which Borso replied that such pomp was not due to vanity but instead aimed at increasing the prestige of the house. ${ }^{39}$ It is commonplace but nonetheless correct to note that, after the peace of Lodi, Italian states relied more on their

37 Italian Renaissance Diplomacy, pp. 200-01.

${ }^{38}$ Ibid., p. 201. To be sure of the excellent quality of each individual gift, Borso relied, for fabrics and embroidery, on craftsmen who served the court. See: Marcello Toffanelli, Le arti a Ferrara nel Quattrocento: gli artisti e la corte (Ferrara: Edisai, 2010), p. 376. The guitars, on the other hand, had been specially purchased in Venice: Emilio Motta, 'Musici alla Corte degli Sforza (Ricerche e documenti milanesi)', Archivio Storico Lombardo, 5th ser., 2 (1887), 29-64 (p. 54).

39 Micaela Torboli, Il duca Borso d'Este e la politica delle immagini nella Ferrara del Quattrocento (Ferrara: Cartografica, 2007), pp. 34-35. 
reputation and diplomatic ability than on the strength of their armies. As Folin writes, 'the ostentation of magnificence was one of the main pillars of a careful dynastic policy'. ${ }^{40}$ Borso had the reputation of surrounding himself with luxury, but also of being a shrewd administrator. When paying homage to the King of Tunis, he justifies himself for the humility of certain gifts (straw hats, bells) by appealing to the exotic curiosity that Uthman could have nurtured towards Western objects:

we have decided to send you to visit His Majesty, with some things that here in Italy we customarily use among us, according to Italian traditions. And even though they are not very precious things since His Majesty deserves more dignified and precious gifts, we nevertheless send them for pleasure and courtesy so that he can see and know how things are different from the ways and customs there, and so these things that we send offer a record of our deeds and of our generosity and friendship, which we hope not just to preserve, but to augment and grow. ${ }^{41}$

Perhaps because he was aware that his squires were not used to travelling abroad, probably because he wanted to define every detail of the mission according to his personal taste, Borso gave his squires extremely detailed instructions. To make the presentation of gifts more spectacular, Borso wanted more than 60 porters, in pairs or individually, to carry them. ${ }^{42}$ In the face of far greater interests, such as the maintenance of commercial treaties functional to the economy of the Venetian Republic, Borso spent significantly more on the presentation of gifts: according to Ugo Caleffini, bungling flatterer of the Marquis but also in charge of transcribing his accounting records, he spent 11,000 liras; ${ }^{43}$ according

40 Marco Folin, Rinascimento estense: politica, cultura, istituzioni di un antico Stato italiano (Roma-Bari: Laterza, 2004), p. 166.

41 Italian Renaissance Diplomacy, pp. 197-98.

42 Since a complete bibliography on the symbolism of political power in the Middle Ages would occupy too much space, I will just quote Maria Antonietta Visceglia, Riti di corte e simboli della regalità: I regni d'Europa e del Mediterraneo dal medioevo all'età moderna (Rome: Salerno Editrice, 2009).

43 On the figure of Caleffini, see: Beatrice Saletti, 'Registri perduti della Camera Ducale estense: la 'Storia della città di Ferrara' del notaio Ugo Caleffini e il suo accesso alla libreria della Camera', in Archivi, ufficiali e società in Italia tra medioevo e età moderna, atti del Convegno di Studi, ed. by Flippo De Vivo, Andrea Guidi, Alessandro Silvestri (Roma: Viella, 2015), pp. 285-310. 
to Cesare Foucard, who found some payments in the court expense records, at least 1500 liras. ${ }^{44}$ Even taking the lowest figure, it is difficult to understand the usefulness of such an expense. As Guido Guerzoni has verified, the financial system was precisely managed down to the smallest detail; ${ }^{45}$ yet in everyday life of a Renaissance court, spontaneous gifts and donations seem habitual. A very interesting example concerns the economy of remission: a theme well analysed by Laura Turchi as it relates to Este's rule in the sixteenth century, but still wholly unexplored concerning to medieval Ferrara. ${ }^{46}$ By sampling a 1459 register, containing details of the fines for criminal convictions and the respective sums collected, it turns out that the difference between the money owed and the money actually collected is enormous: Borso had waived the money owed by about ninety per cent of those sentenced, even when the amounts due were considerable. ${ }^{47}$ It can be confusing for today's scholars to read pages and pages of notes, dates, circumstances, names of debtors and debt collectors in charge, and then find that such a work did not lead to actual collections. ${ }^{48}$ Both the enormous expenses of

${ }^{44}$ Relazioni dei Duchi, p. 19.

45 Guido Guerzoni, 'La Camera Ducale Estense tra Quattro e Cinquecento: la struttura organizzativa e i meccanismi operativi', in Storia di Ferrara ed. by Adriano Prosperi, 7 vols. (Ferrara: Corbo, 1987-2004), VI (2000), pp. 160-83.

${ }^{46}$ Laura Turchi, La giustizia del principe. Ricerche sul caso estense secoli $X V-X V I$ (Modena: Bulzoni, 2005).

${ }^{47}$ ASMo, Maleficia, b. 3.

48 The policy of remissions on the part of the rulers is still a little known subject, despite Clavero and Hespanha's now classic works on the dependence of the juridical regulatory universe on other regulatory spheres (like moral and religious ones, and feelings like love and friendship): Bartolomé Clavero, Antidora: antropologia catolica de la economia moderna (Milano: Giuffrè, 1991); Antonio M. Hespanha, La gracia del derecho: economia de la cultura en la edad moderna (Madrid: Centro de estudios constitucionales, 1993). In Hespanha's work it emerges that the exercise of justice by the sovereign is a place of transaction between authority and various subjects (classes, communities). Perhaps for this reason, many historians prefer to examine political action, or narrative, as Zemon Davis does in Fiction in the Archives: Pardon Tales and Their Tellers in Sixteenth-Century France (Stanford: Stanford University Press, 1987), and neglect the economic aspect of not collecting fines: Maria Nadia Covini, 'De Gratia speciali. Sperimentazioni documentarie e pratiche di potere tra I Visconti e gli Sforza', in Tecniche di potere nel tardo Medioevo: regimi comunali e signorie in Italia, ed. by Massimo Vallerani (Roma: Viella, 2010), pp. 183-205. 
representing themselves abroad, such as those made for the mission in Tunis, and the waiving of subjects' debts, were part of a culture, a way of life for Renaissance rulers that, in no small extent, we still have to understand.

We do not know what the squires reported to Borso about their mission in 1464. Nevertheless, we are aware of the visit that an envoy for Uthman made to Ferrara the following winter, with an entourage of 14, reciprocating the marquis' gifts: horses, greyhounds, 'and other kindnesses' ${ }^{49} \mathrm{I}$ have not yet found traces of gifts brought back to the King of Tunis, only of a personal present to the ambassador: embroidered fabrics and a tapestry. ${ }^{50}$

A singular but still under-investigated aspect of the exchange of diplomatic gifts is that of re-gifting. This is what happened, for example, to part of the gift (specifically, two civets) delivered to Borso by an ambassador of the Sultan of Egypt, who travelled to Italy in March 1465 to negotiate with Venice and went to Ferrara to pay homage to the Marquis. One year later, according to a letter from the Marquis, one of the two animals was to be sent to Cardinal Francesco Gonzaga. ${ }^{51} \mathrm{We}$ can deduce that the practice of re-gifting was common, or at least not rare, from the fact that we find it a few decades later also in Venice: on 23 April 1506, a Tunisian ambassador gave the Venetian authorities a gift from his king - two Great Danes and three falcons. Less than a month later, on 16 May, Venice sent these very same animals as gifts to Emperor Maximilian I. ${ }^{52}$ Some gifts, in particular, seem to have been considered

49 Ferrara, Biblioteca Comunale Ariostea (hereafter cited as BCAFe), MS Classe I 757, Giuliano e Giacomo Antigini, Annali di Ferrara dal 1384 al 1514, fol. 27r: 'Uno ambasadore del re de Tunexi de Barbaria vene circha a dì 20 de dexembre 1464 a Ferara cum circha a 14 persone che fu mandado da quel re a donare al ducha Borso certi prexenti xoè chavali barbari, livereri, tele sotile, e altre zentileze, e steteno a Ferara fino ala fine de febraro'.

50 Relazioni dei Duchi, p. 5.

51 ASMo, Casa e Stato, Carteggio referendari, b. 2a, Letter from Marquis Borso d'Este to his referendario, 27 March 1466. I do not go into any more detail on this ambassador from Egypt to Ferrara because Chroniclers describe the issue in vague and inconsistent terms and restrictions due to COVID-19 prevented me from carrying out archival research on the matter.

52 Marino Sanudo il Giovane, Diarii, ed. by Rinaldo Fulin et al., 58 vols (Venice: Visentini, 1879-1903), VI (1891), coll. 331 and 339. 
appropriate for re-gifting, including dogs, falcons and horses suitable for hunting, or exotic animals. Unfortunately, we have no information as to a possible scale of the monetary value or artistic excellence of the objects that should be presented to a marquis, a duke, a king or an emperor. We know of single gifts of exceptional value, but it remains impossible to evaluate whether there was a minimum level of quality for gift, or what that level was. On 30 November 1469, the vicar of the episcopal curia of Modena sent Borso a letter accompanied by pears, and Borso replied to him that those were most welcome and would have been a sufficient and honourable gift to an emperor. ${ }^{53}$ In any case, the required standards for a gift given from a subordinate like this were lower than for a gift presented by a head of state.

\section{CONCLUSION}

A lavish lifestyle, unlimited patronage of the arts, the manifestation of his power through the erection of numerous and majestic buildings, promotion of the university: all these aspects characterized Borso's politics. Generosity and magnificence had been the tools that Borso had used to obtain the title of duke: only after receiving his extremely luxurious hospitality did Emperor Frederick II agree to grant him the title. ${ }^{54}$ Widening the focus from the Po valley, after the fall of Byzantium and the West's fear of the grand Turk, trade networks in the Mediterranean changed dramatically. One of the reactions was that diplomacy among Hafsid and Western rulers was invigorated. In his instructions, Borso commanded his squires to thank Uthman for the right to trade in his territories, but he was referring only to the purchase of horses. We do not know if Borso would have wanted, in his great ambition, to obtain economic or political advantages from the Hafsid kingdom: to date, no documents on this matter have emerged. Any way, the trip to Tunis by Borso's squires was not just a whim, but a gesture of acute political foresight. Most likely, he intended to show his power to other Italian rulers, and certainly to his subjects. Giuliano Antigini and Ugo Caleffini,

53 ASMo, Leggi e decreti, C/II, fol. 12.

54 Werner Gundersheimer, Ferrara Estense. Lo stile del potere (Modena: Panini, 1988), pp. 65-66. 
authors of as yet unpublished chronicles, recall that: 'All the lords of the world loved Borso, and were aware of his lordship. Even the king of Tunis of Barbaria sent him an ambassador with some fine gifts; ${ }^{25}$ and 'In his time, there was war almost all over the world, everywhere except in his land. And in Ferrara, he was always judge of all peace treaties, and he had been loved and honoured even by the Turks. ${ }^{56}$

The fact that even a chronicler from outside the court environment like Antigini considered the visit of ambassadors from Tunis to be Borso's top diplomatic goal seems to confirm that the Marquis achieved his purpose.

\section{BIBLIOGRAPHY}

\section{Archival Sources}

Modena, Archivio di Stato:

Carteggio principi esteri, Ambasciatori dal Levante: b. 1

Camera Ducale, Carteggio di referendari, consiglieri, cancellieri e segretari: b. 2a, b. $2 b$

Leggi e decreti: C/II

Maleficia: b. 3

Ferrara, Biblioteca Comunale Ariostea:

MS Classe I 757: Giuliano e Giacomo Antigini, Annali di Ferrara dal 1384 al 1514

Florence, Biblioteca Nazionale Centrale:

MS Magliabechiano Classe XXV 539: Ugo Caleffini, Storia della città di Ferrara dal suo principio sino all'anno 1471

55 BCAFe, Giuliano e Giacomo Antigini, Annali di Ferrara dal 1384 al 1514, fol. 9r: 'Tuti li signori del mondo ge voleva bene et avevano notitia dela soa duchale e gratiosissima signoria. Fina al re de Tunixi de Barbaria ge mandò una ambasaria cum certi beli prexenti'.

56 Florence, Biblioteca Nazionale Centrale, MS Magliabechiano Classe XXV 539, Ugo Caleffini, Storia della città di Ferrara dal suo principio sino all'anno 1471, fol. 56v: 'Et per lo suo tempo quasi per tuto le parte del mondo fu guerra, eccetto che da casa sua. Et sempre in Ferrara lui fu iudice di tuti li acordi dele guere, et insino da Turchi era stato amato, et apresentato'. 


\section{Printed Primary Sources}

Catellacci, Dante, 'Diario di Felice Brancacci ambasciatore con Carlo Federighi al Cairo per il comune di Firenze', Archivio Storico Italiano, 8th ser., 8 (1881), 157-88

Dispacci sforzeschi da Napoli: 4 luglio 1454 - 30 dicembre 1459, ed. by Francesco Senatore (Salerno: Carlone, 1997)

Italian Renaissance Diplomacy: A Sourcebook, ed. by Monica Azzolini and Isabella Lazzarini (Durham-Toronto: Institute of Medieval and Early Modern Studies, Durham University-Pontifical Institute of Medieval Studies, 2017)

Marino Sanudo il Giovane, Diarii, ed. by Rinaldo Fulin et al., 58 vols (Venice: Visentini, 1879-1903)

Marino Sanudo il Giovane, Le vite dei dogi (1474-1494), ed. by Angela Caracciolo Aricò, 2 vols (Roma-Padova: Antenore, 1989-2001)

Osio, Luigi, Documenti diplomatici tratti dagli archivi milanesi (Milan: Tipografia di Giuseppe Bernardoni di Giovanni, 1869)

Relazioni dei Duchi di Ferrara e di Modena coi Re di Tunisi ed. by Cesare Foucard (Modena: litografia Pizzolotti, 1881)

\section{Secondary Works}

Behrens-Abouseif, Doris, Practising Diplomacy in the Mamluk Sultanate (London: Tauris, 2014)

Buckler, Francis W., Harunu'l-Rashid and Charles the Great (Cambridge: Mediaeval Academy of America, 1931)

Cerone, Francesco, 'La politica orientale di Alfonso di Aragona', Archivio Storico per le Province Napoletane, 27 (1902), 380-456

Cheal, David, The Gift Economy (London: Routledge, 1988)

Chevallier, Bernard, 'Sévres et l'Egypte', in Napoleone Bonaparte in Egitto: una spedizione tra conquista e conoscenza 1798-1801, ed. by Cristina Cannelli, Giulia Gorgone, Luigi Mascilli Migliorini (Roma: Gangemi, 2000), pp. 65-76

Chiappini, Luciano, 'Borso d'Este', Dizionario Biografico degli Italiani (Roma, Istituto dell'Enciclopedia Italiana, 1960-), XIII (1971), pp. 134-43

Clavero, Bartolomé, Antidora: antropologia catolica de la economia moderna (Milano: Giuffrè, 1991)

Constable, Olivia Remie, Housing the Stranger in the Mediterranean World: Lodging, Trade, and Travel in Late Antiquity and the Middle Ages (Cambridge: Cambridge University Press, 2003)

Covini, Maria Nadia, 'De Gratia speciali. Sperimentazioni documentarie e pratiche di potere tra I Visconti e gli Sforza', in Tecniche di potere nel tardo Medioevo: regimi comunali e signorie in Italia, ed. by Massimo Vallerani (Roma: Viella, 2010), pp. 183-205

Figliuolo, Bruno, 'La Terrasanta nel quadro della politica orientale di Alfonso V d'Aragona', Nuova Rivista Storica, 100, no. 2 (2016), 483-516 
Folin, Marco, Rinascimento estense: politica, cultura, istituzioni di un antico Stato italiano (Roma-Bari: Laterza, 2004)

Frati, Lodovico, 'Due umanisti bolognesi alla Corte ducale di Milano', Archivio Storico Italiano, 5th ser., 43 (1909), 359-73

Godelier Maurice, L'Énigme du don (Paris: Fayard, 1996)

González Arévalo, Raúl, 'Italian Renaissance Diplomacy and Commerce with Western Mediterranean Islam: Venice, Florence, and the Nasrid Kingdom of Granada in the Fifteenth Century', I Tatti Studies in the Italian Renaissance, 18 (2015), 215-32

Groebner, Valentin, Liquid Assets, Dangerous Gifts: Presents and Politics at the End of the Middle Ages (Philadelphia: University of Pennsylvania Press, 2002)

Guerzoni, Guido, 'La Camera Ducale Estense tra Quattro e Cinquecento: la struttura organizzativa e i meccanismi operativi', in Storia di Ferrara ed. by Adriano Prosperi, 7 vols. (Ferrara: Corbo, 1987-2004), VI (2000), pp. 160-83

— La colonia sotto casa (Torino - London: Umberto Allemandi \& C., 2008) Gundersheimer, Werner, Ferrara Estense. Lo stile del potere (Modena: Panini, 1988) Hespanha, Antonio M., La gracia del derecho: economia de la cultura en la edad moderna (Madrid: Centro de estudios constitucionales, 1993)

Lazzarini, Isabella, Communication and Conflict: Italian Diplomacy in the Early Renaissance, 1350-1520 (Oxford: Oxford University Press, 2015)

Marengo, Emilio 'Genova e Tunisi (1388-1515)', Atti della Società Ligure di Storia Patria, 5th ser., 32 (1902)

Mauss, Marcel, 'Essai sur le don. Forme et raison de l'échange dans les sociétés archaïques', L’Année sociologique, n.s. 1 (1925), 30-186

Motta, Emilio, 'Musici alla Corte degli Sforza (Ricerche e documenti milanesi)', Archivio Storico Lombardo, 5th ser., 2 (1887), 29-64

Negotiating the Gift: Pre-modern Figurations of Exchange, ed. by Gadi Algazi, Valentin Groebner, Bernhard Jussen (Göttingen: Vandenhoeck \& Ruprecht, 2003)

Petti Balbi, Giovanna, 'Gli insediamenti genovesi nel Nord-Africa durante il '400', in Medioevo, Mezzogiorno, Mediterraneo. Studi in onore di Mario del Treppo, ed. by Giovanni Vitolo and Gabriella Rossetti (Pisa-Naples: GISEM-Liguori, 2000), pp. 121-37 156 (1998) 227-56

-, 'L'emirato hafside di Tunisi: contatti e scambi con il mondo cristiano (secc. XIII-XVI)', in Africa / Ifrìqiya. Il Maghreb nella storia religiosa di Cristianesimo e Islam, ed. by Luciano Vaccaro (Città del Vaticano-Gazzada: Libreria editrice vaticana-Fondazione ambrosiana Paolo VI), pp. 323-49 2005)

Roberts, Sean, 'The Lost Map of Matteo de' Pasti: Cartography, Diplomacy, and Espionage in the Renaissance Adriatic', Journal of Early Modern History, 20 (2016), 19-38

Ryder, Alan, Alfonso the Magnanimous: King of Aragon, Naples, and Sicily, 1396-1458 (Oxford: Clarendon Press, 1990) 
Sacerdoti, Alberto, 'Venezia e il regno Hafsida di Tunisi. Trattati e relazioni diplomatiche (1231-1534)', Studi Veneziani, 8 (1966), 18-44

Saletti, Beatrice, 'Assente ingiustificata. Per la storia economica di Ferrara nel Tre e Quattrocento', in Centri di produzione, scambio e distribuzione nell'Italia centro-settentrionale. Secoli XIII-XIV, ed. by Bruno Figliuolo (Udine: Forum, 2018), pp. 177-201

, 'Registri perduti della Camera Ducale estense: la 'Storia della città di Ferrara' del notaio Ugo Caleffini e il suo accesso alla libreria della Camera', in Archivi, ufficiali e società in Italia tra medioevo e età moderna, atti del Convegno di Studi, ed. by Flippo De Vivo, Andrea Guidi, Alessandro Silvestri (Roma: Viella, 2015)

Sowerby, Tracey A., 'Early Modern Diplomatic History', History Compass, 14, no. 9 (2016), 441-56

The Languages of Gift in the Early Middle Ages, ed. by Wendy Davies, Paul Fouracre (Cambridge, Cambridge University Press, 2010)

Toffanelli, Marcello, Le arti a Ferrara nel Quattrocento: gli artisti e la corte (Ferrara: Edisai, 2010)

Torboli, Micaela, Il duca Borso d'Este e la politica delle immagini nella Ferrara del Quattrocento (Ferrara: Cartografica, 2007)

Turchi, Laura, La giustizia del principe. Ricerche sul caso estense secoli XV-XVI (Modena: Bulzoni, 2005)

Valérian, Dominique, 'Gênes, l'Afrique et l'Orient: le Maghreb almohade dans la politique génoise en Méditerranée', in Chemins d'outre-mer: Études d'histoire sur la Méditerranée médiévale offertes à Michel Balard, ed. by Damien Coulon, Catherine Otten-Froux, Paule Pagès et al. (Paris: Publications de la Sorbonne, 2004), pp. 827-37

, 'L'essor de l'activité commerciale de la façade maritime du Maghreb aux XIIIe et XIVe siècles', in Les ports et la navigation en Méditerranée au moyen âge, ed. by Ghislaine Fabre, Daniel Leblévec, Denis Menjot (Paris: Editions du Manuscrit, 2009), pp. 225-32

Visceglia, Maria Antonietta, Riti di corte e simboli della regalità: I regni d'Europa e del Mediterraneo dal medioevo all'età moderna (Rome: Salerno Editrice, 2009)

Zemon Davis, Natalie, The Gift in Sixteenth-Century France (Oxford: Oxford University Press, 2000)

- Fiction in the Archives: Pardon Tales and Their Tellers in Sixteenth-Century France (Stanford (Calif.): Stanford University Press, 1987)

Beatrice Saletti - received her first PhDin 2012 and second in 2018, both in medieval history. She lectures in medieval history at the University of Ferrara; until now, she has focused mainly on Holy Land pilgrimages, the history of indulgences, the Este Dynasty, the Franciscan Order, and human mobility in 15th-century Italy; e-mail: beatrice.saletti@unife.it 